\title{
Universiteit
}

Leiden

The Netherlands

\section{Hypotension is more risky than hypertension in very old people}

Engelaer, Frouke M.; Bodegom, David van; Westendorp, Rudi G.J.

\section{Citation}

Engelaer, F. M., Bodegom, D. van, \& Westendorp, R. G. J. (2012). Hypotension is more risky than hypertension in very old people, e721. Retrieved from

https://hdl.handle.net/1887/47474

Version: $\quad$ Not Applicable (or Unknown)

License: $\quad$ Leiden University Non-exclusive license

Downloaded from: https://hdl.handle.net/1887/47474

Note: To cite this publication please use the final published version (if applicable). 


\title{
Hypotension is more risky than hypertension in very old people
}

\author{
Frouke M Engelaer PhD student, David van Bodegom assistant professor of medicine at Leiden \\ University Medical Centre, Rudi G J Westendorp professor of medicine at Leiden University Medical \\ Centre
}

Leyden Academy on Vitality and Ageing, 2333 AA Leiden, Netherlands

The open label treatment extension of the original HYVET study received enthusiastic applause as further evidence for direct and long term benefits of treating hypertension in very old people ( $\geq 80$ years). ${ }^{1}$ However, we should be cautious in extrapolating these findings to clinical practice.

It has repeatedly been shown that hypotension, not hypertension, carries the greatest risk in very old people. ${ }^{2}$ Low blood pressure may be a consequence of imminent heart failure, drug treatment, or both, whereas raised blood pressure may be reactive and can have survival benefits by ensuring perfusion in critical organs. ${ }^{3}$ It is therefore important to estimate the net benefit of blood pressure lowering treatment. The latest Cochrane review on treatment of hypertension in octogenarians weighs all the available evidence, including the HYVET study, but does not show a survival benefit for treatment, the hazard ratio being close to unity. ${ }^{4}$ The HYVET study may be the only trial to show a survival benefit because it recruited healthy octogenarians, as shown by the low levels of comorbidity at baseline and low fatality rate in the placebo group. ${ }^{5}$
The benefits of treating very healthy octogenarians with hypertension definitely outweigh the side effects. But it would be a daunting task for clinicians to correctly identify these older people in clinical practice.

Competing interests: None declared.

1 Beckett N, Peters R, Tuomilehto J, Swift C, Sever P, Potter J, et al; for the HYVET Study Group. Immediate and late benefits of treating very elderly people with hypertension: results from active treatment extension to Hypertension in the Very Elderly randomised controlled trial. BMJ 2012;344:d7541. (4 January.)

2 Van Bemmel T, Gussekloo J, Westendorp RG, Blauw GJ. In a population-based prospective study, no association between high blood pressure and mortality after age 85 years. J Hypertens 2006;24:287-92.

3 Euser SM, van Bemmel T, Schram MT, Gussekloo J, Hofman A, Westendorp RG, et al. The effect of age on the association between blood pressure and cognitive function later in life. J Am Geriatr Soc 2009;57:1232-7.

4 Musini VM, Tejani AM, Basset K, Wright JM. Pharmacotherapy for hypertension in the elderly. Cochrane Database Syst Rev 2009;4:CD000028.

5 Beckett N, Peters R, Fletcher AE, Staessen JA, Liu L, Dumitrascu D, et al. Treatment of hypertension in patients 80 years of age or older. N Engl J Med 2008;358:18.

Cite this as: BMJ 2012;344:e721

๑ BMJ Publishing Group Ltd 2012 